\title{
A Study of Farm Structure Cropping Pattern and Cropping Intensity on Sample Farms in Pratapgarh Dist. U.P. India
}

\author{
Santosh Kumar Mishra ${ }^{*}$, Rajeev Singh, Ram Ashray Singh, \\ Jitendra Kumar Singh and K.K. Singh
}

\author{
Department of Agricultural Economics Narendra Deva University of Agriculture and \\ Technology Kumarganj, Faizabad (U.P.) 224229, India \\ *Corresponding author
}

\section{A B S T R A C T}

\begin{tabular}{|l|}
\hline Keyw ord s \\
$\begin{array}{l}\text { Weighted mean and } \\
\text { Tabular analysis. }\end{array}$ \\
\hline Article Info \\
\hline $\begin{array}{l}\text { Accepted: } \\
\text { 21 July } 2017 \\
\text { Available Online: } \\
\text { 10 September } 2017\end{array}$ \\
\hline
\end{tabular}

Paddy (Oryza sativa L.) is the most important staple food crop in Asia. More than $90 \%$ of the world's paddy is grown and consumed in Asia, where $60 \%$ of the world's population lives. The area under paddy in India was reported 43.95 million hectares with the total production of 106.54 million tonnes, while productivity was recorded 24.249 quintal per hectare. The area under paddy in Utter Pradesh was 5.98 million hectares, and production was 14.63 million tonnes while productivity $24.479 \mathrm{qt} / \mathrm{h}$. Pratapgarh district of Uttar Pradesh was selected purposively in order to avoid operational in convenience. The average size of farm was found i.e. 0.98. On an average, per farm and per hectare investment on fixed assets came to Rs. 2191496.00 and Rs.655002.30, respectively. And overall average gross cropped area 1.87 ha. Cropping intensity witnessed 160.20 per cent.

\section{Introduction}

Paddy (Oryza sativa L.) belongs to the Graminae family is the most important food crops of India and is likely to be continued as dominant food crop in future also. The crop has very wide physiological adaptability being grown in both tropical and temperate condition from sea level to high altitudes and from semi-arid tract of Rajasthan and Punjab to a very wet area of Assam, West Bengal, Kerala and Karnataka. Rice is mainly produced and consumed in the Asian region. India has the largest area under paddy in the world and ranks second in the production after China. Country has also emerged as a major rice consumer.
Rice is primarily a high energy calorie food. The major part of rice consists of carbohydrate in the form of starch, which is about 72-75 percent of the total grain composition. The protein content of rice is around 7 percent. The protein of rice contains glutelin, which is also known as oryzenin. The nutritive value of rice protein (biological value $=80$ ) is much higher than that of wheat (biological value $=60$ ) and maize (biological value $=50$ ) or other cereals. Paddy is grown on an area of 164.72 million hectares with an annual production of 745.71 million tonnes in the world with the productivity of $45.279 \mathrm{q} / \mathrm{ha}$ during 2013. In the world, India ranks first in 
area but second in production after China. In India rice occupies an area of 43.95 million hectares with annual production 106.54 million tones with productivity of $24.249 \mathrm{q} / \mathrm{ha}$ (Anonymous, 2009), While area, production, and productivity in Uttar Pradesh were 5.98 million hectare, 14.63 million tonnes and $24.479 \mathrm{q} /$ hectare respectively.

\section{Materials and Methods}

\section{Technical programme}

Keeping in view the limitation of material resources and time factor, the study was conducted using sample survey method for collection of the relevant information. Sampling design, method of data collection and specification of analytical tools, all these together, constitute the methodological part of present study. The chapter is solely devoted for a detailed discussion on these aspects.

\section{Sampling technique}

The purposive cum random sampling design was used for the selection of district, block, villages and respondents. The district Pratapgarh was selected purposively to avoid the operational inconvenience of the investigator.

Out of 17 blocks of the selected district, one block having highest area under paddy crop was selected purposively. A list of all the villages falling under selected block was prepared and arranged in ascending order according to area covered by paddy crop and 5 villages namely Atroura Meerpur, Sonpura, Deorakha, Ibrahimpur and Pura were selected randomly from the list.

\section{Selection of respondents}

A separate list of paddy growers of selected five villages i.e. Atroura Meerpur, Sonpura,
Deorakha, Ibrahimpur and Purawere prepared along with their size of holdings and further was grouped into three categories i.e.(1) Marginal: below 1 ha (2) Small: 1-2 ha (3) Medium: 2 to 4 ha. From this list a sample of 100 farmers were selected following the proportionate random sampling technique:

\section{Selection of market}

Aspur Deosara where most of the food grains of area are being disposed of as such leading Aspur Deosara / Dhakwa Market was selected for the study of marketing aspect.

\section{Collection of data}

The study consists of both primary and secondary data. For the collection of secondary information, various offices and published records were consulted.

However for the collection of primary field data the survey method was used. The primary data from 100 sample farmers (66 marginal, 24 small and 10 medium sizegroup) were collected through a well prepared and pre tested schedules of enquiry by interview method. The data was pertained to the agricultural year - 2015-16.

\section{Analytical tools}

Suitable statistical tools were applied to analyses the data for the presentation of the results.

\section{Tabular analysis}

Tabular analysis was used to compare the different parameters among marginal, small and medium size group of the farms. Family composition, investment pattern; crop-wise costs and returns etc. were computed and presented in tabular forms. In this computation weighted average were used. 
$\mathrm{W} . \mathrm{A} .=\frac{\sum \mathrm{W}_{\mathrm{i}} \mathrm{X}_{\mathrm{i}}}{\sum \mathrm{W}_{\mathrm{i}}}$

Where,

W. A. $=$ Weighted average

$\mathrm{Xi}=$ Variable

$\mathrm{Wi}=$ Weight of variable

\section{Cropping intensity}

Cropping intensity is the ratio of total cropped area to net cultivated area and have been presented in percentage.

Total cropped area

Cropping intensity $=$

Net cultivated area

\section{Regression analysis}

To study the effect of various independent variables on the dependent variables, various form of production function have been explored. However, Cobb-Douglas production function was found best fit for the analysis of data.

The mathematical form of Cobb-Douglas function (power function) is as follows:

$$
\mathrm{Y}=\mathrm{ax}_{1}{ }^{\mathrm{b}_{1}} \cdot \mathrm{x}_{2}{ }^{\mathrm{b}_{2}} \ldots \ldots \ldots \ldots \ldots \ldots \ldots \mathrm{Xn}^{\mathrm{bn}}
$$

Where,

$\mathrm{Y}=$ Dependent variable (output value in rupees/hectare)

$\mathrm{X}_{1}=\mathrm{i}^{\text {th }}$ independent variable (input value rupees/hectare)

$\mathrm{a}=$ Constant

$\mathrm{b}_{1}=$ Production elasticity with respect to $\mathrm{X}_{\mathrm{i} \text { 's }}$
The value of the constant (a) and coefficient (bi) in respect of independent variable in the function have been estimated by using the method of least square. The Cobb-Douglas production function in log form is as follows:

$\log Y=\log a+b_{1} \log X_{1}+b_{2} \log X_{2}+b_{3} \log$ $\mathrm{X}_{3}+\mathrm{b}_{4} \log \mathrm{X}_{4}+\ldots+\mathrm{u} \log \mathrm{e}$

Where,

$\mathrm{Y}=$ Value of gross returns of crops (Rs./ha)

$\mathrm{X}_{1}=$ Expenditure on human labour (Rs./ha)

$\mathrm{X}_{2}=$ Expenditure on seed $(\mathrm{Rs} . / \mathrm{ha})$

$\mathrm{X}_{3}=$ Expenditure on manure and fertilizer (Rs./ha)

$\mathrm{X}_{4}=$ Expenditure on irrigation (Rs./ha)

$\mathrm{e}=$ error

$\mathrm{a}=$ Intercept

$b_{i}:(j=1,2 \ldots \ldots .4)$ are the elasticity coefficient of the $\mathrm{j}^{\text {th }}$

\section{Marginal Value Product (MVP)}

The marginal value product of inputs were estimated by following formula:

$(M V P) X_{j}=b_{j} \frac{\bar{Y}}{\bar{X}_{j}}$

Where,

$b_{j}=$ Production elasticity with respect to $X_{j}$

$\bar{Y}_{j}=$ Geometric mean of the dependent variable $\mathrm{Y}$

$\bar{X}_{j}=$ Geometric mean value of $X_{j}$ 
MVP $=$ Marginal value product of $\mathrm{j}^{\text {th }}$ input

Having estimates of the elasticity coefficients, it is desirable to ascertain the reliability of these estimates. The most commonly used ' $t$ ' test was applied to ascertain whether the sample production elasticity coefficient ; bj is significantly different from zero or not at some specified probability level.

' $t$ ' cal $=b_{j} /$ standard error of $b_{j}$

If cal. ' $t$ ' is greater than table value of $t$ distribution at (n-k-1) degree of freedom and specified probability level of significance, $b_{j}$ is said to be statistically significant from zer $\mathrm{K}$ is number of independent variable and $\mathrm{n}$ is sample size.

\section{Results and Discussion}

This chapter deals mainly with the findings of the present study i.e. farm structure, cropping pattern, investment on farm, cropping intensity, cost of cultivation, measures of costs and farm incomes, regression analysis, marginal value productivities, extent of marketable and marketed surplus, pattern of disposal, producer's share in consumer's rupee, marketing costs and margins, price spreads in different marketing channels and their relative marketing efficiency, constraints of production and marketing.

\section{Structure of farms}

The study on the structure of sample farms and family are of significant importance as these influence the resource use pattern on farms. The structure of farm family highlights overall condition within and around the farms such as size of holding, family size, age, cropping pattern and cropping intensity etc.

The characters existing on sample farms are discussed in following page.

\section{Average size of holding}

The size of holding is supposed to positively correlate with volume of food grains production. The farmers having larger size of holding are economic better off and they are in a position to adopt easily the improved farm practices. On the other hand, the farmer having smaller farm unit have been desired to produce as much they can with a view to marketing both their ends meet and also to improve their economic condition shown as table 1 .

This table indicates that overall average size of farms was found to be 0.98 ha, which varied from 0.54 ha on marginal, 1.47 ha on small and 2.65 ha on medium farms along with total cultivated area 98.08 ha on sample farms.

\section{Composition of sample farm families according to age}

Table 2 shows the distribution of sample population by size of farms.

Out of total sample population viz., 962, children were constituted 29.73 per cent, adult 47.92 per cent and old age 22.35 per cent. It was noticed that major composition of family member belongs to age group of 15-55 yrs shown in table 2 .

\section{Size of family according to size of farms}

Size of family is of great importance in the context of agricultural occupation. Large family size indicates more working force of the family and may be utilized as labour force at the time of various operations of the farms. The average family size of sample farm is given in table 3 .

Table 3 indicates that average size of farm family was 20.97 which show increasing 
trend with increase in size of farms and varied from 8.11to 6.46 persons per farms.

\section{Per farm investment on fixed capital}

Table 4 exhibits per farm investment on different components of fixed assets under different size group of farms. Present value of investment on farm building (Residence, cattle-shed and godown) was observed to be Rs. 859016.00 (35.36), 794146.65 (36.88) and 294486.75 (41.23) under marginal, small and medium size farm, respectively.

Investment on machinery and implements under marginal, small and medium farms were found to be Rs. 283619.00 (11.68), Rs. 223336.63 (10.33) and Rs. 32027.36 (4.43) respectively.

Investment on livestock under marginal, small and medium farms was found to be Rs. 72008.00 (2.964), Rs. 59132.00 (59.132) and Rs. 30612.79 (4.286), respectively. Total investment on marginal, small and medium farm was worked out to be Rs. 2429236.00
(100), Rs. 2153231.00 (100) and Rs. 714254.00 (100), respectively. Per farm total investment shows increasing trend with increasing size group of farms. On an overall average of size group of farms as it was worked out to be Rs. 2191496.00 (100).

\section{Per hectare investment on fixed capital}

Per hectare investment for different components. Investment on farm building (residence, cattle-shed, and implements shed), machinery livestock and other under different size group of farms has been presented in table 5 .

On an overall average, investment on farm building, machinery and implements and livestock per hectare was worked out and it came to Rs. 521518.50, 86151.13 and 49746.71, respectively. Total investment on marginal, small and medium size group of farms were found to be Rs.902161.70, Rs.1464783.00 and Rs. 1314701.00, respectively. On all farms total investment per hectare was found to be Rs. 655002.30.

\section{Village-wise proportionate selection of sample farmers under different size group of farms}

\begin{tabular}{|l|l|l|l|l|l|l|l|c|}
\hline \multirow{4}{*}{\begin{tabular}{c}
\multirow{4}{*}{$\begin{array}{c}\text { Name } \\
\text { of villages }\end{array}$} \\
\cline { 2 - 10 }
\end{tabular}} & \multicolumn{2}{c|}{ Marginal } & \multicolumn{2}{c|}{ Small } & \multicolumn{2}{c|}{ Medium } & \multicolumn{2}{c|}{ Total } \\
\cline { 2 - 9 } & $\mathbf{P}$ & $\mathbf{S}$ & $\mathbf{P}$ & $\mathbf{S}$ & $\mathbf{P}$ & $\mathbf{S}$ & $\mathbf{P}$ & S \\
\hline AtrouraMeerpur & 102 & 16 & 23 & 4 & 13 & 2 & 138 & 21 \\
\hline Sonpura & 83 & 14 & 28 & 5 & 13 & 2 & 124 & 21 \\
\hline Deorakha & 68 & 12 & 38 & 6 & 09 & 1 & 115 & 19 \\
\hline Ibrahimpur & 90 & 15 & 33 & 5 & 15 & 2 & 138 & 23 \\
\hline Pura & 67 & 09 & 33 & 4 & 14 & 3 & 114 & 16 \\
\hline Total & 410 & 66 & 155 & 24 & 64 & 10 & 629 & 100 \\
\hline
\end{tabular}

Note: $\mathrm{P}=$ Total number of households, $\mathrm{S}=$ Selected number of households

Table.1 Average size of sample farmers by size of farms (ha.)

\begin{tabular}{|c|c|c|c|c|}
\hline S. No. & Size of farm & Number of farms & Total cultivated area & Average size of farm \\
\hline 1 & Marginal (Below-1 ha.) & 66 & $36.17(36.87)$ & 0.54 \\
\hline 2 & Small (1 - 2 ha.) & 24 & $35.41(36.10)$ & 1.47 \\
\hline 3 & Medium (2 - 4 ha.) & 10 & $26.50(27.01)$ & 2.65 \\
\hline \multicolumn{2}{|c|}{ Total } & 100 & $98.08(100)$ & 0.98 \\
\hline
\end{tabular}

Note- Figures in parenthesis show the percentage to total. 
Table.2 Age wise family composition of sample farmers

\begin{tabular}{|c|c|c|c|c|c|}
\hline S. No. & Farm family size & Total Population & Children below 15 yrs. & Adult 15-55 yrs. & Old above 55 yrs. \\
\hline \multirow{2}{*}{1.} & Marginal & 435 & 125 & 190 & 120 \\
& $($ Below -1 ha. $)$ & $(100)$ & $(12.99)$ & $(19.75)$ & $(12.47)$ \\
\hline \multirow{2}{*}{2.} & Small $(1-2$ ha. $)$ & 316 & 91 & 165 & 60 \\
& & $(100)$ & $(9.46)$ & $(17.15)$ & $(6.24)$ \\
\hline \multirow{2}{*}{3.} & Medium & 211 & 70 & 106 & 35 \\
& $(2-4$ ha. $)$ & $(100)$ & $(7.28)$ & $461.02)$ & $(3.64)$ \\
\hline \multicolumn{2}{|c|}{ Total } & 962 & 286 & $(47.92)$ & $(22.35)$ \\
\hline
\end{tabular}

Note- Figures in parenthesis show the percentage to total.

Table.3 Average family size of sample of farms

\begin{tabular}{|c|c|c|c|c|c|}
\hline \multirow{2}{*}{ S. No. } & \multirow{2}{*}{ Size of farm } & \multirow{2}{*}{$\begin{array}{l}\text { No of sample } \\
\text { farms }\end{array}$} & \multicolumn{3}{|c|}{ Average number of sample farm family } \\
\hline & & & Male & Female & Total \\
\hline 1 & $\begin{array}{c}\text { Marginal } \\
\text { (Below -1 ha.) }\end{array}$ & 66 & $\begin{array}{c}4.39 \\
(38.88)\end{array}$ & $\begin{array}{c}3.72 \\
(38.47)\end{array}$ & $\begin{array}{c}8.11 \\
(38.67)\end{array}$ \\
\hline 2 & $\begin{array}{c}\text { Small } \\
(1-2 \text { ha. })\end{array}$ & 24 & $\begin{array}{c}3.50 \\
(31.00) \\
\end{array}$ & $\begin{array}{c}2.95 \\
(30.51) \\
\end{array}$ & $\begin{array}{c}6.46 \\
(30.81) \\
\end{array}$ \\
\hline 3 & $\begin{array}{l}\text { Medium } \\
(2-4 \text { ha. })\end{array}$ & 10 & $\begin{array}{c}3.40 \\
(30.12)\end{array}$ & $\begin{array}{c}3.00 \\
(31.02)\end{array}$ & $\begin{array}{c}6.40 \\
(30.52)\end{array}$ \\
\hline & Total & 100 & $11.29(100)$ & $9.67(100)$ & $20.97(100)$ \\
\hline
\end{tabular}

Note: Figures in parenthesis show the percentage to total.

Table.4 Per farm investment on different size group of farms (Rs)

\begin{tabular}{|l|l|c|c|c|c|}
\hline \multirow{2}{*}{ S. } & \multirow{2}{*}{ Particulars } & \multicolumn{4}{|c|}{ Size of farms } \\
\cline { 3 - 6 } & & Marginal & Small & Medium & Overall average \\
\hline $\mathbf{1 .}$ & Buildings & 859016.00 & 794146.65 & 294486.75 & 786994.431 \\
& & $(35.36)$ & $(36.88)$ & $(41.23)$ & $(35.91)$ \\
\hline a. & Residential & 820008.00 & 727858.15 & 286188.66 & 744510.102 \\
& & $(33.76)$ & $(33.8)$ & $(40.07)$ & $(33.97)$ \\
\hline b. & Cattle shed & 39008.00 & 66288.50 & 8298.09 & 42484.329 \\
& & $(1.606)$ & $(3.079)$ & $(1.162)$ & $(1.139)$ \\
\hline $\mathbf{2 .}$ & Machinery and & 283619.00 & 223336.63 & 32027.36 & 243992.067 \\
& Implements & $(11.68)$ & $(10.37)$ & $(4.484)$ & $(11.13)$ \\
\hline a. & Major Implements & 280616.00 & 220703.13 & 31643.92 & 241339.703 \\
& & $(11.55)$ & $(10.25)$ & $(4.43)$ & $(11.13)$ \\
\hline b. & Minor Implements & 2953.00 & 2633.50 & 383.44 & 2619.364 \\
& & $(0.122)$ & $(0.122)$ & $(0.054)$ & $(0.12)$ \\
\hline $\mathbf{3})$ & Live stock & 72008.00 & 59132.00 & 30612.79 & 64778.239 \\
& & $(2.964$ & $(2.746)$ & $(4.286)$ & $(2.956)$ \\
\hline a. & Buffalo & 27004.00 & 17504.00 & 10654.17 & 23089.017 \\
& & $(1.112)$ & $(0.813)$ & $(1.492)$ & $(1.054)$ \\
\hline b. & Cow & 45004.00 & 41254.00 & 17854.17 & 41389.017 \\
& & $(1.853)$ & $(1.916)$ & $(2.5)$ & $(1.889)$ \\
\hline c. & Goat & 0.00 & 374.00 & 2104.45 & 300.205 \\
& & $(0.000)$ & $(0.017)$ & $(0.295)$ & $(0.014)$ \\
\hline $\mathbf{( 4 )}$ & Grand total & $2429236(100)$ & $2153231(100)$ & $714254(100)$ & $2191496(100)$ \\
\hline
\end{tabular}

Figures in parenthesis show the percentage to total. 
Table.5 Per hectare investment on different size group of farms (Rs)

\begin{tabular}{|c|c|c|c|c|c|}
\hline \multirow{2}{*}{ S. No. } & \multirow{2}{*}{ Particulars } & \multicolumn{4}{|c|}{ Size of farms } \\
\hline & & Marginal & Small & Medium & Overall average \\
\hline 1. & Buildings & $\begin{array}{c}319336.8 \\
(35.40)\end{array}$ & $\begin{array}{c}540235.816 \\
(36.88)\end{array}$ & $\begin{array}{c}545345.83 \\
(41.23)\end{array}$ & $\begin{array}{c}\mathbf{5 2 1 5 1 8 . 5} \\
(39.67)\end{array}$ \\
\hline a. & Residential & $\begin{array}{c}304835.69 \\
(33.79)\end{array}$ & $\begin{array}{c}495141.599 \\
(33.80)\end{array}$ & $\begin{array}{l}\mathbf{5 2 9 9 7 9} \\
(40.07)\end{array}$ & $\begin{array}{c}499103.7 \\
(37.96)\end{array}$ \\
\hline$[b$. & Cattle shed & $\begin{array}{c}14501.115 \\
(1.61)\end{array}$ & $\begin{array}{c}45094.2177 \\
(3.80)\end{array}$ & $\begin{array}{c}15366.8333 \\
(1.16)\end{array}$ & $\begin{array}{c}22414.83 \\
(1.71)\end{array}$ \\
\hline 2. & $\begin{array}{l}\text { Machinery and } \\
\text { Implements }\end{array}$ & $\begin{array}{c}105434.57 \\
(11.69)\end{array}$ & $\begin{array}{c}151929.68 \\
(10.37)\end{array}$ & $\begin{array}{c}59309.9259 \\
(4.48)\end{array}$ & $\begin{array}{c}86151.13 \\
(6.55)\end{array}$ \\
\hline a. & Major Implements & $\begin{array}{c}103418.22 \\
(11.46)\end{array}$ & $\begin{array}{c}150138.184 \\
(10.25)\end{array}$ & $\begin{array}{c}58599.8519 \\
(4.43)\end{array}$ & $\begin{array}{c}85050.89 \\
(6.47)\end{array}$ \\
\hline b. & Minor Implements & $\begin{array}{c}1097.7695 \\
(0.12) \\
\end{array}$ & $\begin{array}{c}1791.4966 \\
(0.12)\end{array}$ & $\begin{array}{c}710.074074 \\
(0.05)\end{array}$ & $\begin{array}{c}1008.385 \\
(0.77) \\
\end{array}$ \\
\hline (3) & Live stock & $\begin{array}{c}26768.773 \\
(2.97)\end{array}$ & $\begin{array}{l}40225.8503 \\
(2.75)\end{array}$ & $\begin{array}{c}56690.3519 \\
(4.29)\end{array}$ & $\begin{array}{c}49746.71 \\
(3.78)\end{array}$ \\
\hline a. & Buffalo & $\begin{array}{c}10038.622 \\
(1.11)\end{array}$ & $\begin{array}{c}11907.483 \\
(0.81)\end{array}$ & $\begin{array}{c}19729.9444 \\
(1.49)\end{array}$ & $\begin{array}{c}16843.42 \\
(1.28)\end{array}$ \\
\hline b. & Cow & $\begin{array}{c}16730.112 \\
(1.85)\end{array}$ & $\begin{array}{c}28063.9456 \\
(1.92)\end{array}$ & $\begin{array}{c}33063.2778 \\
(2.50\end{array}$ & $\begin{array}{c}30230.12 \\
(2.30)\end{array}$ \\
\hline c. & Goat & 0.00 & $\begin{array}{c}254.421769 \\
(0.01)\end{array}$ & $\begin{array}{c}3897.12963 \\
(0.29)\end{array}$ & $\begin{array}{c}2633.167 \\
(0.20)\end{array}$ \\
\hline (4) & Grand total & $\begin{array}{c}902161.70 \\
(100)\end{array}$ & $\begin{array}{c}1464783 \\
(100)\end{array}$ & $\begin{array}{c}1314701 \\
(100)\end{array}$ & $\begin{array}{c}655002.3 \\
(100)\end{array}$ \\
\hline
\end{tabular}

Note- Figures in parenthesis show the per cent to total.

Table.6 Cropping pattern on different size group of farms (ha)

\begin{tabular}{|c|c|c|c|c|c|}
\hline \multirow{2}{*}{ S. No. } & \multirow{2}{*}{ Size group of farm } & \multicolumn{4}{|c|}{ Size group of farms } \\
\hline & & Marginal & Small & Medium & Overall average \\
\hline A. & Kharif & $\begin{array}{c}0.44 \\
(39.60)\end{array}$ & $\begin{array}{c}1.23 \\
(44.73)\end{array}$ & $\begin{array}{c}2.36 \\
(49.48)\end{array}$ & $\begin{array}{c}\mathbf{0 . 8 2} \\
(43.90)\end{array}$ \\
\hline 1. & Rice & $\begin{array}{c}0.40 \\
(36.00) \\
\end{array}$ & $\begin{array}{c}1.10 \\
(40.00)\end{array}$ & $\begin{array}{c}2.10 \\
(44.03)\end{array}$ & $\begin{array}{c}0.74 \\
(39.50) \\
\end{array}$ \\
\hline 2. & Maize & $\begin{array}{c}0.01 \\
(0.90) \\
\end{array}$ & $\begin{array}{c}0.04 \\
(1.45) \\
\end{array}$ & $\begin{array}{c}0.05 \\
(1.05) \\
\end{array}$ & $\begin{array}{c}0.02 \\
(1.13) \\
\end{array}$ \\
\hline 3. & Arhar & $\begin{array}{c}0.02 \\
(1.80) \\
\end{array}$ & $\begin{array}{c}0.07 \\
(2.54) \\
\end{array}$ & $\begin{array}{c}0.18 \\
(3.77) \\
\end{array}$ & $\begin{array}{c}0.05 \\
(2.57) \\
\end{array}$ \\
\hline 4. & Fodder & $\begin{array}{c}0.01 \\
(0.90) \\
\end{array}$ & $\begin{array}{c}0.02 \\
(0.73) \\
\end{array}$ & $\begin{array}{c}0.03 \\
(0.63) \\
\end{array}$ & $\begin{array}{c}0.01 \\
(0.77) \\
\end{array}$ \\
\hline B. & Rabi & $\begin{array}{c}0.52 \\
(46.80)\end{array}$ & $\begin{array}{c}1.22 \\
(44.36)\end{array}$ & $\begin{array}{c}2.01 \\
(42.14)\end{array}$ & $\begin{array}{c}\mathbf{0 . 8 4} \\
(\mathbf{4 4 . 8 0})\end{array}$ \\
\hline 1. & Wheat & $\begin{array}{c}0.28 \\
(25.20)\end{array}$ & $\begin{array}{c}0.75 \\
(26.27)\end{array}$ & $\begin{array}{c}1.05 \\
(22.01)\end{array}$ & $\begin{array}{c}0.47 \\
(25.10)\end{array}$ \\
\hline 2. & Potato & $\begin{array}{c}0.04 \\
(3.60) \\
\end{array}$ & $\begin{array}{c}0.04 \\
(1.45) \\
\end{array}$ & $\begin{array}{c}0.05 \\
(1.05) \\
\end{array}$ & $\begin{array}{c}0.04 \\
(2.19) \\
\end{array}$ \\
\hline 3. & Pea & $\begin{array}{c}0.01 \\
(0.90)\end{array}$ & $\begin{array}{c}0.01 \\
(0.36)\end{array}$ & $\begin{array}{c}0.03 \\
(0.63) \\
\end{array}$ & $\begin{array}{c}0.01 \\
(0.64) \\
\end{array}$ \\
\hline 4. & Chickpea & $\begin{array}{c}0.02 \\
(1.80) \\
\end{array}$ & $\begin{array}{c}0.02 \\
(0.72) \\
\end{array}$ & $\begin{array}{c}0.10 \\
(2.09) \\
\end{array}$ & $\begin{array}{c}0.03 \\
(1.50) \\
\end{array}$ \\
\hline 5 . & Mustard & $\begin{array}{c}0.09 \\
(8.11) \\
\end{array}$ & $\begin{array}{c}0.20 \\
(7.27) \\
\end{array}$ & $\begin{array}{c}0.35 \\
(7.33) \\
\end{array}$ & $\begin{array}{c}0.14 \\
(7.61) \\
\end{array}$ \\
\hline 6. & Lentil & $\begin{array}{c}0.06 \\
(5.41) \\
\end{array}$ & $\begin{array}{c}0.12 \\
(4.36) \\
\end{array}$ & $\begin{array}{c}0.23 \\
(4.82) \\
\end{array}$ & $(4.89)$ \\
\hline 7. & Berseem & $\begin{array}{c}0.01 \\
(0.90)\end{array}$ & $\begin{array}{c}0.04 \\
(1.45) \\
\end{array}$ & $\begin{array}{c}0.12 \\
(2.52) \\
\end{array}$ & $\begin{array}{c}0.03 \\
(1.51) \\
\end{array}$ \\
\hline 8. & Others & $\begin{array}{c}0.01 \\
(0.90)\end{array}$ & $\begin{array}{c}0.04 \\
(1.45)\end{array}$ & $\begin{array}{c}0.08 \\
(1.68)\end{array}$ & $\begin{array}{c}0.02 \\
(1.29)\end{array}$ \\
\hline C. & Zaid & $\begin{array}{c}0.15 \\
(13.50)\end{array}$ & $\begin{array}{c}0.30 \\
(10.91)\end{array}$ & $\begin{array}{c}\mathbf{0 . 4 0} \\
(\mathbf{8 . 3 8})\end{array}$ & $\begin{array}{c}0.21 \\
(11.30)\end{array}$ \\
\hline 1. & Sugarcane & $\begin{array}{c}0.10 \\
(9.01) \\
\end{array}$ & $\begin{array}{c}0.25 \\
(9.09) \\
\end{array}$ & $\begin{array}{c}0.35 \\
(7.34) \\
\end{array}$ & $\begin{array}{c}0.16 \\
(8.61) \\
\end{array}$ \\
\hline 2. & Vegetables+Onion & $\begin{array}{c}0.03 \\
(2.70)\end{array}$ & $\begin{array}{c}0.02 \\
(0.73) \\
\end{array}$ & $\begin{array}{c}0.02 \\
(0.42) \\
\end{array}$ & $\begin{array}{c}0.03 \\
(1.42) \\
\end{array}$ \\
\hline 3. & Mung & $\begin{array}{c}0.02 \\
(1.80)\end{array}$ & $\begin{array}{c}0.03 \\
(1.09) \\
\end{array}$ & $\begin{array}{c}0.03 \\
(0.63) \\
\end{array}$ & $\begin{array}{c}0.02 \\
(1.25) \\
\end{array}$ \\
\hline Gross cro & $d$ area $(A+B+C)$ & $\begin{array}{c}1.11 \\
(100.00)\end{array}$ & $\begin{array}{c}2.75 \\
(100.00)\end{array}$ & $\begin{array}{c}4.77 \\
(100.00) \\
\end{array}$ & $\begin{array}{c}1.87 \\
(100.00)\end{array}$ \\
\hline
\end{tabular}


Table.7 Cropping intensity of different size of farms

\begin{tabular}{|c|c|c|c|c|c|}
\hline S. No. & Size of farms & No. of farms & $\begin{array}{c}\text { Net cultivated area } \\
\text { (ha) }\end{array}$ & $\begin{array}{c}\text { Gross cropped area } \\
\text { (ha) }\end{array}$ & $\begin{array}{c}\text { Cropping } \\
\text { intensity (\%) }\end{array}$ \\
\hline 1 & Marginal & 66 & 0.54 & 1.11 & 205.55 \\
\hline 2 & Small & 24 & 1.47 & 2.75 & 187.07 \\
\hline 3 & Medium & 10 & 2.69 & 4.77 & 177.32 \\
\hline \multicolumn{2}{r|}{ Total } & $\mathbf{1 0 0}$ & $\mathbf{0 . 9 8}$ & $\mathbf{1 . 8 7}$ & $\mathbf{1 6 0 . 2 0}$ \\
\hline
\end{tabular}

\section{Cropping pattern}

Cropping pattern deals with the distribution of land available for cultivation under different crops in particular season during a year. It is most important factor which determines the investment for different inputs on farm and income of farmers based on resource availability and its use under various agroclimatic conditions.

Cropping pattern of sample farms are given in table 7. Net cultivated area under Kharif season marginal, small and medium size of farms was observed to be $0.44,1.23$ and 2.36 ha. and gross cropped area on marginal, small and medium size of farms accounted to be $1.11,2.75$ and 4.77 ha, respectively.

Area under rice on marginal, small and medium size group of farms was calculated as $0.40,1.10$ and 2.10 ha, respectively. Overall percentage share of rice came to be 39.50 per cent among all crops.

\section{Cropping intensity}

Cropping intensity is an index of intensity of land use determined by the numbers of crop grown in a particular area (field) during a year. It has been worked out by dividing the total cropped area from the cultivated area and then multiplied by 100 . Sample farms were calculated $\&$ given in table 7 Shows the maximum cropping intensity was observed (205.55 per cent) on small size of sample farms followed by marginal (187.07 per cent) and medium (177.32 per cent) with an average sample farms came to 160.20 per cent.

Paddy is the most important staple food crop in Asia. More than $90 \%$ of the world's paddy is grown and consumed in Asia, where 60\% of the world's population lives. Paddy accounts for between 35-60\% of the caloric intake of three billion. Over 164.72 million hectares of paddy are planted annually, covering about $10 \%$ of the world's arable land. India is the second largest producer of paddy after China. The area under paddy in India was reported 43.95million hectares (2013-14) with the total production of 106.54 million tonnes, while productivity per hectare was recorded 22.25 quintal during, (2013-14).

In Uttar Pradesh the area of paddy is about 13.84 million hectares and production is 14.41 million tonnes, with productivity of 23.58 quintal per hectare (Anonymous 2013).It has second position in country where as first West Bengal is (14.96 mt). (Directorate of Agriculture U.P., statistical bulletin, 2012-13).L Pratapgarh district is also an important rice producing district of U. P. The area under paddy in the district during 2012-13 was reported 185991 hectare with production of 452575 metric tonnes while productivity was 24.41qt/ha. (Arth Evam Sankhya Prabhag, Pratapgarh district, U.P. 2013-14).

Paddy is also a symbol of both cultural identity and unity. For all these reasons, "Rice is life" and therefore, the United Nations General Assembly (UNGA) during its $57^{\text {th }}$ 
session on $16^{\text {th }}$ December 2002 declared 2004 as the International Year of Rice.

In view the above mentioned facts an empirical evaluation of these factors are necessary, If the desired extent of development is to be continued, there are urgent need to collect information on production \& marketing of paddy which would be great importance to policy makers. Hence the present study entitled "Production and marketing of paddy in Pratapgarh district of Uttar Pradesh" has been under taken with the following objectives:

To study farm structure, farm assets cropping pattern and cropping intensity of sample farms.

To analyse costs and returns input- output relationship and resources use efficiency of sample farms.

To assess marketable and marketed surplus and its determinants.

To examine marketing channel and to work out the marketing cost, marketing margins and marketing efficiency and

To identity the major constraints of production and marketing and to suggest suitable policy implication thereof.

Pratapgarh district of Uttar Pradesh was selected purposively because of convenience of investigator and to avoid difficulties for collection of data due to time and budget constraints. A list of allthe 17 Blocks of Pratapgarh district was prepared and one Block namely Aspur Deosara having highest area under paddy crop was selected purposively for the study. A list of all the villages of the selected block was prepared separately along with the area under paddy and 5 villages were selected randomly. A separate list of all paddy growers of the 5 selected villages was prepared and classified according to size of holdings into three categories i.e. marginal (below $1.0 \mathrm{ha}$ ), small (1.0-2.0 ha) and medium (2.0 to $4.0 \mathrm{ha}$ ). From this list a sample of 100 respondents were selected following the proportionate random sampling technique. A list of all the Mandi Samiti of regulated market of the district was prepared one Mandi Samiti namely Aspur Deosara / Dhakwa Mrket Mandi Pratapgarh situated near by block were selected purposively. A sizeable number of intermediaries were selected and interviewed for assessing imperfections of paddy marketing system. Primary data were collected through personal interview method on well-structured pretested schedule specially designed for the study while secondary data were collected from published/ unpublished record of District and Block, Headquarter, Books, Journals, Periodicals, News bulletins etc.

The data were collected during the agricultural year 2015 - 16 for this study.

Tabular analysis was used to compare the different parameters among marginal, small and medium size group of the farmers. Family composition, investment pattern; crop-wise costs and returns etc. computed and presented in tabular forms. In this computation weighted average were used.

To study the effect of various independent variables on the dependent variables, various form of production function has been dealt. However, Cobb-Douglas function, due to its convenience in estimating elasticity of production and return to scale, has been found best fit to analyse the productivity of resources in this study.

The samples of 100 farmers of selected block were considered for study. Average size of 
holding varied $0.54,1.47$ and 2.96 hectare in respect of marginal, small and medium farms respectively. Investment on fixed capital per farm overall on of farm building, machinery and implements, livestock and others accounted for 35.91,11.13, 2.96 and 0.12 per cent, respectively of the total farm assets. Per farm area under paddy on marginal, small and medium size group of farms was observed to be $0.40,1.10$ and 2.10 ha, respectively, and gross cropped area on marginal, small and medium size of farms accounted to be 1.11, 2.75 and 4.77 ha, respectively. Cropping intensity was observed to be 205.55 per cent on marginal size of sample farms followed by medium (177.32 per cent) and small (187.07 per cent) with an average on sample farms came to 160.20 per cent.

\section{References}

Abeda Sultana, 2012. Rice marketing in Bangladesh: from the perspective of village study at Cox's Bazar district. African Journal of Agricultural Research; 7: 45, 10.

Acharya and Agarwal, 2011. Pattern of disposal of marketed surplus.
Agriculture Marketing in India, 4 (3): 61-63.

Ali, S. Z., Sidhu, R. S. Kamal Vatta 2012. Effectiveness of minimum support price policy for paddy in India with a case study of Punjab. Agricultural Economics Research Review; 25(2):231-242.

Anonymous, 2011-12. Directorate of rice research Haiderabad (A.P.) India

Baba, B.A., Goni, M. and Mohammed, S. 2007. Analysis of resource-use efficiency in rice production in the lake chand area of Borno state, Nigeria. $J$. Sustain. Dev. Agricult. Environ. 3: 3137.

Basavarajappa, D.N., Marutesha, A.M.; Patil, R. and Pasha, A. 2015. Welfare impact analysis of paddy harvester CLAAS30. International Journal of Agricultural Engineering; 8(1):132-135.

Burger, J., Mol, F. and de Gerowitt, B. 2012. Influence of cropping system factors on pesticide use intensity - a multivariate analysis of on-farm data in North East Germany. European Journal of Agronomy; 40:54-63.

\section{How to cite this article:}

Santosh Kumar Mishra, Rajeev Singh, Ram Ashray Singh, Jitendra Kumar Singh and Singh, K.K. 2017. A Study of Farm Structure Cropping Pattern and Cropping Intensity on Sample Farms in Pratapgarh Dist. U.P. Int.J.Curr.Microbiol.App.Sci. 6(9): 1964-1973. doi: https://doi.org/10.20546/ijcmas.2017.609.240 